\title{
Determination of Topographic Factors to Initiate Debris Flow Using Statistical Analysis
}

\author{
Chien-Yuan Chen, Ho-Wen Chen, and Zhao-Jun Chen, Member, IACSIT
}

\begin{abstract}
This study used GIS to determine 19 topographic indexes, four geologic indexes, and two rainfall data derived indexes of the Laonun River Basin, in southern Taiwan. The four topographic factors, including the effective area of basin, elongation ratio of basin, relief energy, and relief volume, were selected among the 19 topographic indexes using the SPSS multi-variable statistical analysis and the principal components analysis. The four topographic factors combine the four geologic factors and two rainfall factors and were selected for estimating debris flow prone creeks. The ten factors were further applied by the Fisher's Discriminant Analysis and Logistic Regression Analysis to evaluate the potentials of debris flow prone creeks in the basin. There were 13 sub-basins initiated debris flows and 41 non-debris flow sub-basins when Typhoon Morakot hit Taiwan in 2009. The validated results show that the correctness of Fisher's model for the samples is $81.48 \%$ and $92.6 \%$ via the Logistic Regression model. Both models showed acceptable accuracy, and the Logistic model had better accuracy herein. The Logistic Regression Analysis was adapted to evaluate the potential of debris flow sub-basins to assist in developing risk management in the basin.
\end{abstract}

Index Terms-Debris flow, GIS, principal components analysis, linear regression analysis.

\section{INTRODUCTION}

Typhoon Morakot hit Taiwan in 2009. The typhoon brought over $2,500 \mathrm{~mm}$ of torrential rainfall in mountainous southern Taiwan. The rainfall was equivalent to a year of rain in Taiwan and caused serious debris flow hazards in southern Taiwan. Most of the serious debris flow hazards occurred in the Laonun river watershed. An efficient prediction model for debris flow warning is necessary to prevent hazards during climate change-induced torrential rainfall.

The initiation of debris flow is accompanied by abundant losses of slope material in high discharge of steep slope. Topographic indexes are shown to be important in initiating the debris flow. Researchers have proposed numerous represented field conditions of rainfall, geologic, and topographic factors that attributed to the initiation of debris flow [1]-[3].

Investigation of potential debris flow creeks has been

Manuscript received April 30, 2014; revised June 26, 2014. This work was supported in part by the National Science Council in Taiwan under Grant NSC 99-2625-M-415-003-MY3.

Chien-Yuan Chen and Zhao-Jun Chen are with the Civil and Water Resources Engineering Department, National Chiayi University, Chiayi City 60004, Taiwan R.O.C. (e-mail: chienyuc@mail.ncyu.edu.tw, tainan946012@yahoo.com.tw).

Ho-Wen Chen is with the Department of Environmental Science and Engineering, Tunghai University, Taichung City 40704, Taiwan R.O.C. (e-mail: hwchen@thu.edu.tw). studied by numerous researchers that collected related topographic and hydrologic factors to initiate debris flow using statistical analysis. Lee [4] studied rainfall threshold for debris flow warning using non-parametric statistics of the Mann-Whitney-Wilcoxon test (MWW test). He extracted four significant factors to initiate debris flow, including mean streambed slope, effective watershed area, landslide ratio, and lithologic characteristic, for the topographic factors analysis and debris flow potential analysis. Wu [5] studied 34 debris flow potential creeks by Multivariate Statistical Analysis to extract main topographic factors using Principal Component Analysis for watershed area, mean slope, form factor, river density, landslide area, geologic index, effective cumulative rainfall, and effective rainfall intensity. The eight factors were further analyzed by Fisher's Discriminant Analysis for debris flow potential analysis.

Rainfall is the main factor attributed to debris flows in Taiwan. Numerous debris flows are initiated during the peak rainfall intensity of a rainfall event in Taiwan [6], [7]. Separating antecedent rainfall and a rainfall event is required before estimating the critical rainfall factors that initiate debris flow. The relationships between rainfall intensity and duration, intensity and cumulative rainfall, and intensity and antecedent cumulative rainfall are commonly used climate factors to construct a predictive relationship for debris flow warning [6], [8], [9].

\section{Study AREA AND METHOdOLOGY}

\section{A. Study Area}

The study area, the Laonun River Basin, is located in Kaoshiun City in southern Taiwan. The Laonun River is a branch of the Gaoping River, the second largest river in Taiwan. Its length is $130 \mathrm{~km}$ with a watershed area of 1,370 $\mathrm{km} 2$ and average gradient of $1 / 43$. Upstream from the watershed is primarily forest with the South Cross-Island Highway cross the valley. Large areas in the middle and downstream areas have been developed for agricultural activities and for hot spring sightseeing. The greater the development of the areas the more vulnerable they are to natural disasters. Its location is shown in Fig. 1.

The Laonun River Basin is located in the south-west area of the Central Mountain Range. Its topography is higher on the north side and lower on the south side, steeper on the east side and flatter on the west side. The main topographic features are piedmont, meander stream channel, valley, terrace, and alluvial fan. Fig. 2 shows sub-basin division and stream network in the basin. 


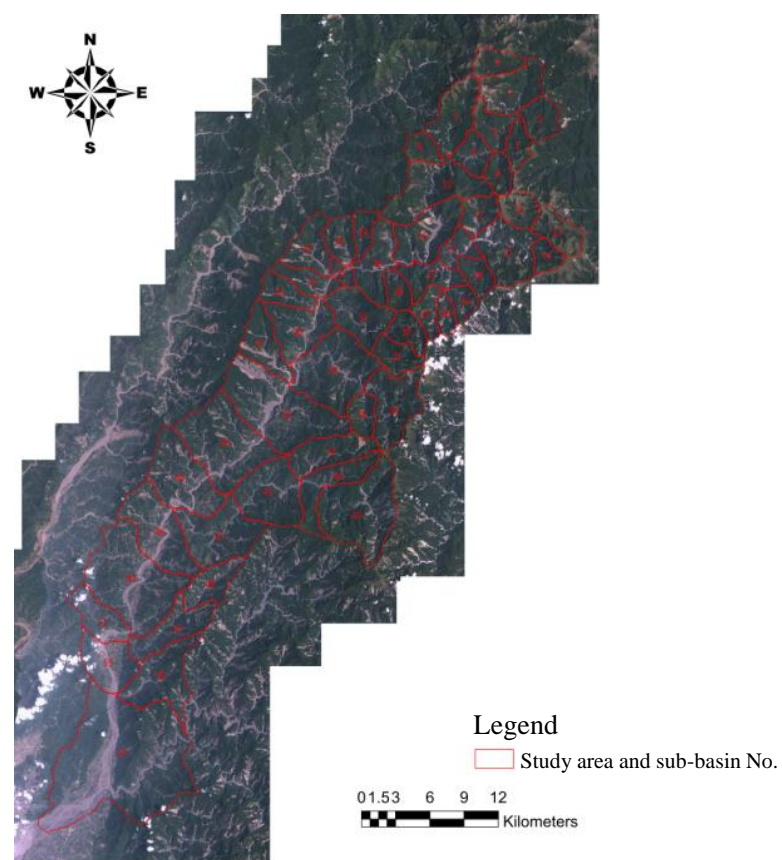

Fig. 1. Study area of the Laonun river basin (satellite image in 2009).

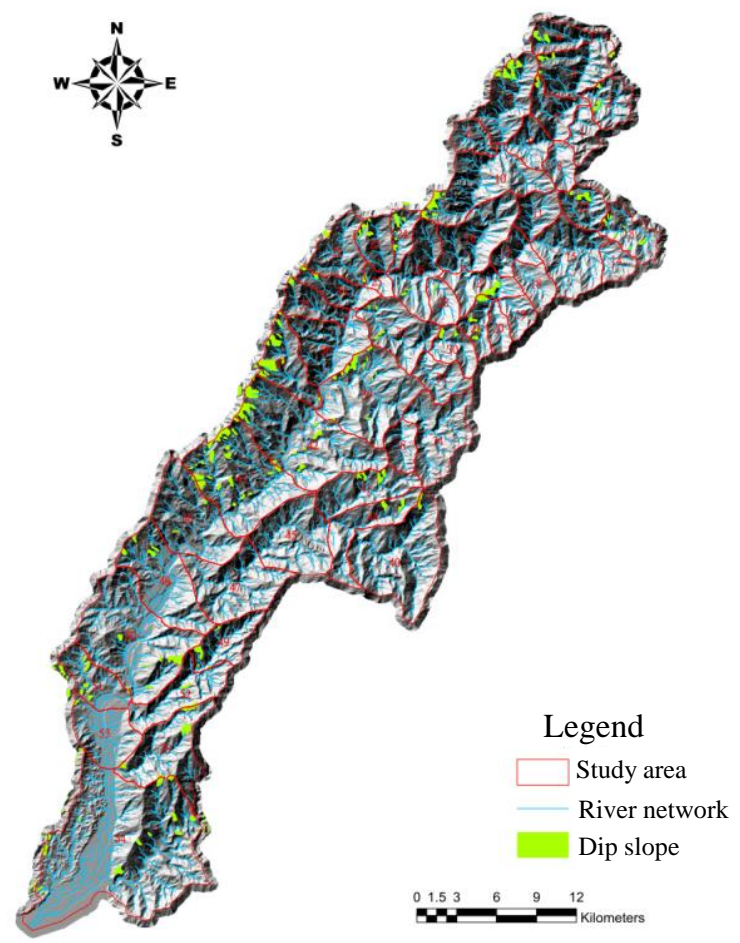

Fig. 2. Basin division, stream network, and dip slope in the study area.

\section{B. Methodology}

The study basin is divided into 54 sub-basins to analyze factors that initiate debris flow. Factors that initiate debris flow include climatic, topographic, and geologic conditions. The climatic factors are sourced from rainfall data and topographic factors are calculated from the digital terrain model $(D T M)$ in $40 \times 40 \mathrm{~m}$. The regional characteristics that initiate debris flow are analyzed using statistical analysis to extract factors that trigger debris flows and their potential analysis for the studied Laonun River Basin. The purpose of this study is to establish a precise model to locate potential debris flow creeks for hazard prevention and mitigation. The analysis methodology can be divided into four parts:

1) Digital database collection: Digital database include satellite images, DTM, rainfall records, and geology maps are collected for the analysis.

2) Debris flow initiation factors database setting: The study using GIS spatial analysis to estimate geologic and topographic factors to initiate debris flow and collection of rainfall records during 2006 to 2009 for climate factors estimation.

3) Extraction initiation factors of debris flow: The study using Principal Component Analysis to check if the topographic factors have significant differences and show independence. A rainfall event is defined for estimating the climate factors; then, extraction of the main affecting factors, including geologic, topographic, and climatic factors, to determine potential of debris flow for further statistical analysis.

4) Test and validation: Statistical Product and Service Solutions package (SPSS) is used for the multi-variable statistical analysis using Fisher's Discriminant Analysis and Logistic Regression Analysis and cross calibration to set a function for debris flow potential assessment.

TABLE I: DEFINITION OF USED TOPOGRAPHIC FACTORS FOR THE ANALYSIS

\begin{tabular}{|c|c|c|c|}
\hline Factors & Symbol & Unit & Definition \\
\hline $\begin{array}{l}\text { Effective } \\
\text { basin area }\end{array}$ & $A_{s}$ & $\mathrm{~km}^{2}$ & cell area for slope over $15^{\circ}$ in the basin \\
\hline $\begin{array}{l}\text { Perimeter } \\
\text { of basin }\end{array}$ & $P$ & $\mathrm{~km}$ & $\begin{array}{l}\text { the length of a map line that encloses } \\
\text { the catchment area of a drainage basin }\end{array}$ \\
\hline $\begin{array}{l}\text { Basin } \\
\text { length }\end{array}$ & $L$ & $\mathrm{~km}$ & $\begin{array}{l}\text { length in a straight line from the mouth } \\
\text { of a stream to the farthest point on the } \\
\text { drainage divide of its basin }\end{array}$ \\
\hline $\begin{array}{l}\text { Length of } \\
\text { main } \\
\text { channel }\end{array}$ & $L_{\mathrm{o}}$ & $\mathrm{km}$ & $\begin{array}{l}\text { the length of the longest succession of } \\
\text { segments that connect a source to the } \\
\text { outlet of the basin }\end{array}$ \\
\hline $\begin{array}{l}\text { Total } \\
\text { stream } \\
\text { length }\end{array}$ & $L_{T}$ & $\mathrm{~km}$ & $\begin{array}{l}\text { summation of main stream's and } \\
\text { branches' length in the basin }\end{array}$ \\
\hline $\begin{array}{l}\text { Mean basin } \\
\text { width }\end{array}$ & $W$ & $\mathrm{~km}$ & $\begin{array}{l}\text { the ratio between the area of the basin } \\
\text { and the length of the main channel }\end{array}$ \\
\hline Sinuousity & $J$ & - & $\begin{array}{l}\text { the ratio of channel length and down } \\
\text { valley path length }\end{array}$ \\
\hline $\begin{array}{l}\text { Number of } \\
\text { streams }\end{array}$ & $N$ & - & $\begin{array}{l}\text { total numbers of main and branch } \\
\text { rivers in the basin }\end{array}$ \\
\hline $\begin{array}{l}\text { Mean basin } \\
\text { elevation }\end{array}$ & $H$ & $\mathrm{~m}$ & $\begin{array}{l}\text { the mean of difference of maximum } \\
\text { and minimum elevation in the basin }\end{array}$ \\
\hline $\begin{array}{l}\text { Relief } \\
\text { energy }\end{array}$ & $R_{f}$ & $\mathrm{~m}$ & maximum difference of elevation \\
\hline Relief ratio & $R_{d}$ & - & $\begin{array}{l}\text { drop in elevation between the river's } \\
\text { source and the river's mouth divided by } \\
\text { the total length of the river }\end{array}$ \\
\hline $\begin{array}{l}\text { Mean basin } \\
\text { slope }\end{array}$ & $S$ & $\%$ & the mean of the basin slope \\
\hline $\begin{array}{l}\text { Mean river } \\
\text { slope }\end{array}$ & $S_{t}$ & $\%$ & $\begin{array}{l}\text { the ratio of drop in elevation of a } \\
\text { stream per unit horizontal distance }\end{array}$ \\
\hline Form factor & $F$ & - & $\begin{array}{l}\text { the ratio between the area of the basin } \\
\text { and the square of the length of the main } \\
\text { channel }\end{array}$ \\
\hline Compactness & $C$ & - & $\begin{array}{l}\text { the ratio between the perimeter of the } \\
\text { basin and the diameter of the circle } \\
\text { having the same area of the basin }\end{array}$ \\
\hline $\begin{array}{l}\text { Circularity } \\
\text { ratio }\end{array}$ & $M$ & - & $\begin{array}{l}\text { the ratio between the area of the basin } \\
\text { and the area of the circle having the } \\
\text { same perimeter of the basin }\end{array}$ \\
\hline $\begin{array}{l}\text { Elongation } \\
\text { ratio }\end{array}$ & E & - & $\begin{array}{l}\text { the ratio between the diameter of the } \\
\text { circle having the same area of the basin } \\
\text { and the length of the main channel }\end{array}$ \\
\hline $\begin{array}{l}\text { Drainage } \\
\text { density }\end{array}$ & $D_{s}$ & - & $\begin{array}{l}\text { the ratio between the total length of the } \\
\text { river network and the basin area }\end{array}$ \\
\hline $\begin{array}{l}\text { Stream } \\
\text { frequency }\end{array}$ & $F_{s}$ & - & $\begin{array}{l}\text { the ratio between the number of the } \\
\text { branches and the area of the basin }\end{array}$ \\
\hline
\end{tabular}




\section{Spatial Database Setting AND Statistical SCREENING ANALYSIS}

Topographic factors of every sub-basin are estimated using spatial analysis in GIS. There are 19 topographic factors in the database including: (1) effective basin area, (2) basin perimeter, (3) basin length, (4) length of main stream, (5) total stream length, (6) mean basin width, (7) sinuousity, (8) number of streams, (9) mean basin elevation, (10) relief energy, (11) relief ratio, (12) mean basin slope, (13) mean river slope, (14) form factor, (15) compactness, (16) circularity ratio, (17) elongation ratio, (18) drainage density, (19) stream frequency (see Table I).

The database of geological factors is sourced from the Central Geological Survey (http://www.moeacgs.gov.tw/) and includes landslide and dip slope area in the basin and Formosa-2 satellite images before and after Typhoon Morakot. The digitalized database includes geological indexes $\left(E_{d}\right)$, fault length, landslide ratio, and ratio of dip slope area (see Table II).

Rainfall isohyets distribution during years 2006 to 2009 showed that downstream area had the higher frequency of debris flows. The results show that high cumulative rainfall is one of the attributing factors to initiate debris flow. The effective cumulative rainfall and effective rainfall intensity are chosen as the climate factors for the analysis (see Table II).

TABLE II: DEFINITION OF GEOLOGICAL AND CLIMATIC FACTORS USED FOR THE ANALYSIS

\begin{tabular}{|c|c|c|c|}
\hline Factors & Symbol & unit & Definition \\
\hline $\begin{array}{l}\text { Geologic } \\
\text { index }\end{array}$ & $E_{d}$ & $\mathrm{~km}^{2}$ & $\begin{array}{l}\mathrm{E}_{\mathrm{d}}=\left(\sum \mathrm{A}_{\mathrm{i}} \times \mathrm{W}\right) / \mathrm{A} \\
\mathrm{A}_{\mathrm{i}}: \text { area of rock type } \mathrm{i}\left(\mathrm{km}^{2}\right) \\
\mathrm{A}: \text { sub-basin area }\left(\mathrm{km}^{2}\right) \\
\mathrm{W}: \text { weight (unit-free) }\end{array}$ \\
\hline $\begin{array}{l}\text { Fault length } \\
\text { ratio }\end{array}$ & $F_{L}$ & $\mathrm{~km}$ & $\begin{array}{l}\mathrm{F}_{\mathrm{L}}=\mathrm{L} / \mathrm{P} \\
\mathrm{L}: \text { fault length }(\mathrm{km}) \\
\mathrm{P}: \text { premium of basin }(\mathrm{km})\end{array}$ \\
\hline $\begin{array}{l}\text { Landslide } \\
\text { ratio }\end{array}$ & $G$ & $\mathrm{~km}^{2}$ & $\begin{array}{l}\mathrm{G}=\mathrm{g} / \mathrm{A} \\
\mathrm{g}: \text { landslide area }\left(\mathrm{km}^{2}\right) \\
\mathrm{A}: \text { basin area }\left(\mathrm{km}^{2}\right)\end{array}$ \\
\hline $\begin{array}{l}\text { Dip slope } \\
\text { area ratio }\end{array}$ & $D_{A}$ & $\mathrm{~km}^{2}$ & $\begin{array}{l}\mathrm{D}_{\mathrm{A}}=\mathrm{D}_{\mathrm{a}} / \mathrm{A} \\
\mathrm{D}_{\mathrm{a}}: \text { dip slope area }\left(\mathrm{km}^{2}\right) \\
\mathrm{A}: \text { basin area }\left(\mathrm{km}^{2}\right)\end{array}$ \\
\hline $\begin{array}{l}\text { effective } \\
\text { cumulative } \\
\text { rainfall }\end{array}$ & $R_{w}$ & $\mathrm{~mm}$ & $\begin{array}{l}\mathrm{R}_{\mathrm{e}}=\alpha_{1} \mathrm{~d}_{1}+\alpha_{2} \mathrm{~d}_{2}+\ldots+\alpha_{14} \mathrm{~d}_{14}= \\
\sum_{t=1}^{14} \alpha_{t} d_{t} \\
\alpha_{\mathrm{t}}=0.5^{\mathrm{t} / \mathrm{T}} \\
\alpha_{\mathrm{t}}=\text { attenuation coefficient, } \mathrm{d}_{\mathrm{t}} \\
(\mathrm{mm})=\text { daily rainfall of } \mathrm{t} \text { day, } \mathrm{T}= \\
\text { half-life, used one day }\end{array}$ \\
\hline $\begin{array}{l}\text { effective } \\
\text { rainfall } \\
\text { intensity }\end{array}$ & $I_{w}$ & $\begin{array}{l}\mathrm{mm} / \\
\mathrm{hr}\end{array}$ & $\begin{array}{l}\mathrm{I}_{\mathrm{w}}=\mathrm{R}_{\mathrm{w}} / \mathrm{T}_{\mathrm{w}} \\
\mathrm{T}_{\mathrm{w}}=\text { effective rainfall duration by } \\
\text { average of the three nearest rain } \\
\text { gauge stations during the initiation } \\
\text { of debris flow }\end{array}$ \\
\hline
\end{tabular}

\section{RESUlTS AND DISCUSSION}

We first used the Kolomogorov-Smironv test to check if the topographic factors show normal distribution. Then, we adopted one of the two methods for "Test for Difference between Means" for the different factors. One-Way ANOVA test (analysis of variance, ANOVA) was used if the factors showed normality; and, the non-parametric Mann-Whitney-Wilcoxon test (MWW test) was used if the factors exhibited non-normality and to find significant effects among the different factors.

\section{A. Kolomogorov-Smironv Test (K-S Test)}

The study used the Kolomogorov-Smironv test (K-S test) to test if the 19 topographic factors showed normal distribution (normality). The level of significance in the K-S test was set as 0.01 ; a level of significance greater than 0.01 is accepted and rejected if smaller than 0.01 . The test results show that the three factors for mean basin width $(W)$, mean river slope $(S)$, and form factor $(F)$ showed a level of significance smaller than 0.01 (see Table III). The overall factors showed non-normality for the 19 geologic factors. The MWW test is adopted for the test of difference between means.

TABLE III: K-S TEST DATA TABLE

\begin{tabular}{lccccc}
\hline \hline Factors & mean & std dev & min & max & $\begin{array}{c}\text { Level of } \\
\text { significance }\end{array}$ \\
\hline$A_{s}(\mathrm{~km})$ & 16.4681 & 12.2543 & 3.4427 & 68.0326 & 0.400 \\
$P(\mathrm{~km})$ & 18.9306 & 7.9454 & 8.4635 & 52.3784 & 0.480 \\
$L(\mathrm{~km})$ & 5.9840 & 2.2523 & 2.5063 & 15.8583 & 0.217 \\
$L_{\mathrm{o}}(\mathrm{km})$ & 6.3666 & 2.8442 & 2.0919 & 17.7624 & 0.693 \\
$L_{T}(\mathrm{~km})$ & 28.9432 & 29.0145 & 5.3540 & 191.2645 & 0.190 \\
$W(\mathrm{~km})$ & 2.9013 & 2.0247 & 1.1121 & 12.7360 & $\underline{0.005}$ \\
$J$ & 1.3681 & 0.3018 & 0.4430 & 2.2423 & 0.235 \\
$N$ & 7.8704 & 3.4644 & 2.0000 & 16.0000 & 0.498 \\
$H(\mathrm{~m})$ & 1993.509 & 724.5209 & 517.3529 & 3205.040 & 0.245 \\
$R_{f}(\mathrm{~m})$ & 1643.333 & 396.0703 & 720.0000 & 2380.000 & 0.972 \\
$R_{d}$ & 0.3396 & 0.1010 & 0.1507 & 0.5448 & 0.968 \\
$S(\%)$ & 32.0422 & 5.1678 & 14.4800 & 38.9600 & 0.053 \\
$S_{t}(\%)$ & 1.5461 & 0.0419 & 1.3424 & 1.5684 & $\underline{0.000}$ \\
$F$ & 0.5885 & 0.7366 & 0.1829 & 4.4621 & $\underline{0.000}$ \\
$C$ & 0.7702 & 0.0772 & 0.5494 & 0.9012 & 0.665 \\
$M$ & 0.5990 & 0.1160 & 0.3019 & 0.8122 & 0.883 \\
$E$ & 0.3841 & 0.0558 & 0.2730 & 0.5055 & 0.988 \\
$D_{s}$ & 0.0015 & 0.0002 & 0.0010 & 0.0022 & 0.505 \\
$F_{s}$ & $5.57 \mathrm{E}-07$ & $2.61 \mathrm{E}-07$ & $1.38 \mathrm{E}-07$ & $1.15 \mathrm{E}-06$ & 0.799 \\
\hline \hline
\end{tabular}

\section{B. Non-Parametric Mann-Whitney-Wilcoxon Test (MWW Test)}

The MWW test assumed samples show non-normality to compare two samples' differences. The process of the test is to separate the 54 sub-basins into two parts of with and without debris flows initiated by historical records. The basins without debris flow creeks is identified (ID) as $\ulcorner 0\lrcorner$ (validation set), and $\ulcorner 1\lrcorner$ for those with debris flow creeks (training set). The significance level is defined as 0.01 , smaller than 0.01 is rejected as no significant difference among these factors. Results of the MWW test (Table IV) for the 19 topographic factors show that the following 12 topographic factors showed significant differences (a significance level greater than 0.01) including effective basin area $\left(A_{s}\right)$, length of main stream $(L)$, width of basin $(W)$, sinuousity $(J)$, relief energy $\left(R_{f}\right)$, relief ratio $\left(R_{d}\right)$, form factor $(F)$, compactness $(C)$, circularity ratio $(M)$, elongation ratio $(E)$, drainage density $(D)$, and stream frequency $\left(F_{s}\right)$.

\section{Topographic Factors Screening Analysis Using Principal Component Analysis}

There are up to 12 sub-basins' topographic factors that showed significant differences following mutual verification by comparing the K-S test (see Table III) and MWW test (see 
Table IV), and therefore need to be further reduced. The study used linear combination of statistical model to screen debris flow potential factors by Factor Analysis in multi-variable statistics of Principal Component Analysis (PCA) and fit Correlation Analysis using a correlation coefficient matrix. The purpose of performing PCA was to screen out the factors that show the largest differences or are independent of others. A Pearson Correlation Matrix was used to standardize and transfer the data from different units of factors. The factor of standardized correlation coefficient is between -1 and +1 and shows the lowest correlation with other factors as the correlation coefficient close to 0 , and vice versa as the absolute value close to 1 . The selection of principal components follows the Kaiser rule [10] for the factor's corresponding initial eigenvalue $(\lambda)$ with $\lambda \geqq 1$ and the level of significance is defined as the absolute value of eigenvectors over 0.7 [11]. In general, a higher absolute value of eigenvector shows a close correlation between the two factors and high absolute value of eigenvector of factor is chosen by Pearson correlation coefficient matrix. The order of first principal component is stream frequency, effective basin area, circularity ratio, compactness, and relief ratio by the ranking of the absolute value of eigenvectors (Tables V and VI). It is found that the effective basin area has a higher significant (absolute value of eigenvector) than others and is selected as the first principal component.

TABLE IV: MANN-WHITNEY-WILCOXON TEST DATA TABLE

\begin{tabular}{|c|c|c|c|c|c|c|c|c|}
\hline Factors & ID & No. & mean & Sum & $\begin{array}{c}\mathrm{U} \\
\text { value }\end{array}$ & $\begin{array}{c}\text { Wilcoxon } \\
\mathrm{W} \\
\end{array}$ & $\begin{array}{c}\mathrm{Z} \\
\text { value }\end{array}$ & $\begin{array}{c}\text { Level of } \\
\text { significance }\end{array}$ \\
\hline \multirow{2}{*}{$A_{s}(\mathrm{~km})$} & 0 & 41 & 24.3659 & 999 & \multirow{2}{*}{138} & \multirow{2}{*}{999} & \multirow{2}{*}{-2.5999} & \multirow{2}{*}{0.010} \\
\hline & 1 & 13 & 37.3846 & 486 & & & & \\
\hline \multirow{2}{*}{$P(\mathrm{~km})$} & 0 & 41 & 24.2927 & 996 & \multirow{2}{*}{135} & \multirow{2}{*}{996} & \multirow{2}{*}{-2.6606} & \multirow{2}{*}{$\underline{0.008}$} \\
\hline & 1 & 13 & 37.6154 & 489 & & & & \\
\hline \multirow{2}{*}{$L(\mathrm{~km})$} & 0 & 41 & 23.9268 & 981 & \multirow{2}{*}{120} & \multirow{2}{*}{981} & \multirow{2}{*}{-2.9640} & \multirow{2}{*}{$\underline{0.004}$} \\
\hline & 1 & 13 & 38.7692 & 504 & & & & \\
\hline \multirow{2}{*}{$L_{0}(\mathrm{~km})$} & 0 & 41 & 25.7805 & 1057 & \multirow{2}{*}{196} & \multirow{2}{*}{1057} & \multirow{2}{*}{-1.4264} & \multirow{2}{*}{0.154} \\
\hline & 1 & 13 & 32.9231 & 428 & & & & \\
\hline \multirow{2}{*}{$L_{T}(\mathrm{~km})$} & 0 & 41 & 23.5854 & 967 & \multirow{2}{*}{106} & \multirow{2}{*}{967} & \multirow{2}{*}{-3.2473} & \multirow{2}{*}{$\underline{0.002}$} \\
\hline & 1 & 13 & 39.8462 & 518 & & & & \\
\hline$W(\mathrm{~km})$ & 0 & 41 & 24.4146 & 1001 & 140 & 1001 & -25594 & 0011 \\
\hline$w(\mathrm{Km})$ & 1 & 13 & 37.2308 & 484 & 140 & 1001 & -2.5594 & 0.011 \\
\hline$J$ & 0 & 41 & 27.3659 & 1122 & 261 & 1122 & -01113 & 0.912 \\
\hline$J$ & 1 & 13 & 27.9231 & 363 & 201 & 1122 & -0.1113 & 0.912 \\
\hline$N$ & 0 & 41 & 24.1829 & 991.5 & 130.5 & 991.5 & -2.7652 & 0006 \\
\hline$N$ & 1 & 13 & 37.9615 & 493.5 & 130.5 & 991.5 & -2.1052 & 0.000 \\
\hline$H(\mathrm{~m})$ & 0 & 41 & 32.1220 & 1317 & 77 & 168 & -38340 & 0001 \\
\hline & 1 & 13 & 12.9231 & 168 & 11 & 108 & -3.8340 & $\underline{0.001}$ \\
\hline$R_{f}$ & 0 & 41 & 29.0488 & 1191 & 203 & 294 & 2851 & 0199 \\
\hline$K_{f}$ & 1 & 13 & 22.6154 & 294 & 203 & 294 & .2851 & 0.199 \\
\hline$R_{d}$ & 0 & 41 & 30.0488 & 1232 & 162 & 253 & -2.1143 & 0.035 \\
\hline & 1 & 13 & 19.4615 & 253 & & & & \\
\hline$S(\%)$ & 0 & 41 & 31.2683 & 1282 & 112 & 203 & -3.1261 & 0.002 \\
\hline & 1 & 13 & 15.6154 & 203 & & & & \\
\hline$S_{L}(\%)$ & 0 & 41 & 31.2927 & 1283 & 111 & 202 & -3.1461 & 0.002 \\
\hline & 1 & 13 & 15.5385 & 202 & & & & \\
\hline$F$ & 0 & 41 & 25.5366 & 1047 & 186 & 1047 & -1.6287 & 0.104 \\
\hline & 1 & 13 & 33.6923 & 438 & & & & \\
\hline$C$ & 0 & 41 & 27.5122 & 1128 & 266 & 357 & -0.0101 & 0.992 \\
\hline & 1 & 13 & 27.4615 & 357 & 200 & 531 & & \\
\hline$M$ & 0 & 41 & 27.5122 & 1128 & 266 & 357 & -0.0101 & 0.992 \\
\hline & 1 & 13 & 27.4615 & 357 & & & & \\
\hline E & 0 & 41 & 27.3415 & 1121 & 260 & 1121 & -0.1315 & 0.896 \\
\hline & 1 & 13 & 28.0000 & 364 & 200 & & & \\
\hline$D_{s}$ & 0 & 41 & 24.5610 & 1007 & 146 & 1007 & -2.4380 & 0.015 \\
\hline$D_{s}$ & 1 & 13 & 36.7692 & 478 & & & & \\
\hline$F_{s}$ & 0 & 41 & 30.0488 & 1232 & 162 & 253 & -2.1143 & 0.035 \\
\hline Ts $s$ & 1 & 13 & 19.4615 & 253 & & & & \\
\hline
\end{tabular}

The second principal components for absolute value of eigenvectors over 0.7 include effective basin area and mean basin width. The two factors have close correlation, considering the fact that the form factor is more commonly used and is higher in significance than the mean basin width. Form factor is selected as the second principal component. The third principal component is elongation ratio and the fourth principal component is Relief energy. In summary, the four factors for effective basin area, form factor, elongation ratio, and relief energy are chosen as the effective principal components for the following analysis.

TABLE V: INITIAL EIGENVALUE AND TOTAL VARIANCES EXPLAINED TABLE

\begin{tabular}{lcccccc}
\multicolumn{3}{c}{ TABLE V: INITIAL EIGENVALUE AND TOTAL VARIANCES EXPLAINED TABLE } \\
\cline { 2 - 7 } & \multicolumn{3}{c}{ Initial eigenvalues } & \multicolumn{3}{c}{ Extraction sums of squared } \\
loadings \\
\cline { 2 - 7 } No. & total & $\begin{array}{c}\text { Variance } \\
(\%)\end{array}$ & $\begin{array}{c}\text { Cumulative } \\
(\%)\end{array}$ & total & $\begin{array}{c}\text { Variance } \\
(\%)\end{array}$ & $\begin{array}{c}\text { Cumulative } \\
(\%)\end{array}$ \\
\hline 1 & $\underline{3.825}$ & 31.872 & 31.872 & 3.825 & 31.872 & 31.872 \\
2 & $\underline{2.496}$ & 20.797 & 52.669 & 2.496 & 20.797 & 52.669 \\
3 & $\underline{1.936}$ & 16.133 & 68.802 & 1.936 & 16.133 & 68.802 \\
4 & $\underline{1.353}$ & 11.278 & 80.080 & 1.353 & 11.278 & 80.080 \\
5 & 0.885 & 7.378 & 87.458 & 0.885 & 7.378 & 87.458 \\
6 & 0.708 & 5.904 & 93.362 & 0.708 & 5.904 & 93.362 \\
7 & 0.348 & 2.898 & 96.260 & 0.348 & 2.898 & 96.260 \\
8 & 0.246 & 2.052 & 98.313 & 0.246 & 2.052 & 98.313 \\
9 & 0.140 & 1.169 & 99.481 & 0.140 & 1.169 & 99.481 \\
10 & 0.051 & 0.421 & 99.903 & 0.051 & 0.421 & 99.903 \\
11 & 0.010 & 0.082 & 99.985 & 0.010 & 0.082 & 99.985 \\
12 & 0.002 & 0.015 & 100.000 & 0.002 & 0.015 & 100.000 \\
\hline \hline
\end{tabular}

TABLE VI: COMPONENT MATRIX AND VALUE OF EIGENVECTOR OF FACTORS IN PRINCIPAL COMPONENT ANALYSIS

\begin{tabular}{lcccc}
\hline \hline & \multicolumn{4}{c}{ Component } \\
\cline { 2 - 5 } Factor & 1 & 2 & 3 & 4 \\
\hline$A_{S}\left(\mathrm{~km}^{2}\right)$ & $\underline{-0.778}$ & 0.148 & 0.517 & 0.076 \\
$L_{0}(\mathrm{~km})$ & -0.677 & -0.515 & 0.352 & 0.100 \\
$W(\mathrm{~km})$ & -0.515 & $\underline{0.796}$ & 0.231 & -0.123 \\
$J$ & -0.289 & -0.691 & 0.349 & 0.155 \\
$R_{f}(\mathrm{~m})$ & -0.238 & 0.255 & -0.120 & $\underline{0.817}$ \\
$R_{d}$ & $\underline{0.702}$ & 0.238 & -0.166 & 0.452 \\
$F$ & -0.190 & $\underline{0.914}$ & -0.141 & -0.111 \\
$C$ & $\underline{0.727}$ & 0.116 & 0.612 & -0.041 \\
$M$ & $\underline{0.735}$ & 0.130 & 0.598 & -0.034 \\
$E$ & 0.156 & 0.257 & $\underline{0.751}$ & 0.176 \\
$D_{s}$ & 0.152 & -0.024 & 0.031 & -0.608 \\
$F_{S}$ & $\underline{0.843}$ & -0.205 & -0.101 & 0.099 \\
\hline \hline
\end{tabular}

There were 10 factors used for the following discriminant and regression analyses for debris flow potential analysis and calculation of its correctness. The selected independent variable includes 4 topographic factors (effective basin area, form factor, elongation ratio, and relief energy), 4 geologic factors (geologic index, fault length, landslide ratio, and ratio of dip slope area), and 2 climatic factors (effective cumulative rainfall and effective rainfall intensity).

The database of 10 factors were selected as dependent variables (outcome variable), and were divided into two categories, the first category $\ulcorner 1\lrcorner$ of 13 sub-basins with records of debris flow and the second category $\ulcorner 0\lrcorner$ of 41 sub-basins without debris flow records.

\section{1) Fisher's discriminant analysis}

The results of Fisher's Discriminant Analysis are function coefficient by the classification coefficient of variables (Table VII). The discriminant functions for category $\ulcorner 1\lrcorner$ and category $\ulcorner 0\lrcorner$ are listed as follows: 
$Y_{1}=\left(0.549 * A_{\mathrm{s}}\right)+(1.391 * F)+(47.249 * E)+\left(-0.002 * R_{f}\right)+$ $\left(-0.923 * E_{d}\right)+\left(-124.904 * F_{L}\right)+(2.949 * G)+\left(42.177 * D_{A}\right)+$ $\left(0.068 * R_{W}\right)+\left(8.414 * I_{W}\right)-142.941$

$Y_{0}=\left(0.318 * A_{s}\right)+(0.276 * F)+(63.941 * E)+\left(0.003 * R_{f}\right)+$ $\left(-0.627 * E_{d}\right)+\left(-143.363 * F_{L}\right)+(2.452 * G)+\left(55.851 * D_{A}\right)+$ $\left(0.061 * R_{W}\right)+\left(7.940 * I_{W}\right)-134.263$

$Y=Y_{1}-Y_{0}=0.231 A_{s}+1.115 F-16.692 E-0.005 R_{f}-0.296 E_{d}$ $+18.459 F_{L}+0.497 G-13.674 D_{A}+0.007 R_{W}-0.474 I_{W}-8.678$

In the equations, $Y_{0}$ is the discriminate function for non-debris flow sub-basins and $Y_{1}$ is for debris flow sub-basins. $Y$ is the overall discriminate function for debris flow sub-basins if the value of $Y$ is greater than 0 , and for non-debris flow sub-basins if the value is smaller than 0 .

A training sample model was adopted to reduce bias (over fitting) and error rate in calculation of the correctness in discriminant analysis in SPSS. The holdout samples method randomly separates the samples into two sets for the training set used for finding the discriminate function of equation and the validation set used for correctness calculation of the discriminate function. The two sets are then changed and the process is repeated for cross validation for the correctness of analysis. The correctness is $88.89 \%$ for the training set, $74.07 \%$ for the validation set, and has overall correctness $81.48 \%$ using Fisher's Discriminant Analysis (see Table VIII).

TABLE VII: COEFFICIENTS OF CLASSIFICATION FUNCTIONS BY FISHER'S

\begin{tabular}{lrrr}
\hline & \multicolumn{2}{c}{ DISCRIMINANT ANALYSIS } \\
\cline { 2 - 3 } Factor & \multicolumn{2}{c}{ category } & \multicolumn{2}{c}{$\begin{array}{c}\text { coefficient of } \\
\text { function } \\
(=\ulcorner 1\lrcorner-\ulcorner 0\lrcorner)\end{array}$} \\
\cline { 2 - 3 }$F\left(\mathrm{~km}^{2}\right)$ & 0.318 & 0.549 & 0.231 \\
$E$ & 0.276 & 1.391 & 1.115 \\
$R_{f}(\mathrm{~m})$ & 63.941 & 47.249 & -16.692 \\
$E_{d}$ & 0.003 & -0.002 & -0.005 \\
$F_{L}$ & -0.627 & -0.923 & -0.296 \\
$G$ & -143.363 & -124.904 & 18.459 \\
$D_{A}$ & 2.452 & 2.949 & 0.497 \\
$R_{w}(\mathrm{~mm})$ & 55.851 & 42.177 & -13.674 \\
$I_{w}(\mathrm{~mm} / \mathrm{hr})$ & 0.061 & 0.068 & 0.007 \\
constant & 7.940 & 8.414 & 0.474 \\
\hline \hline
\end{tabular}

TABLE VIII: RESULTS OF DISCRIMINANT FUNCTION ANALYSIS BY FISHER'S DISCRIMINANT ANALYSIS

\begin{tabular}{|c|c|c|c|}
\hline \multicolumn{3}{|c|}{ Number of training set (54 data) } & \multirow[t]{2}{*}{ sum } \\
\hline category & 0 & 1 & \\
\hline 0 & $39(95.1 \%)$ & $2(4.9 \%)$ & $41(100 \%)$ \\
\hline 1 & $4(30.8 \%)$ & $9(69.2 \%)$ & $13(100 \%)$ \\
\hline \multicolumn{4}{|c|}{ correctness: $[(39+9) /(41+13)] \times 100 \%=88.89 \%$} \\
\hline \multicolumn{3}{|c|}{ Number of validation set (54 data) } & sum \\
\hline category & 0 & 1 & \\
\hline 0 & $32(78 \%)$ & $9(22 \%)$ & $41(100 \%)$ \\
\hline 1 & $5(38.5 \%)$ & $8(61.5 \%)$ & $13(100 \%)$ \\
\hline \multicolumn{4}{|c|}{ correctness: $[(32+8) /(41+13)] \times 100 \%=74.07 \%$} \\
\hline \multicolumn{3}{|c|}{ Number of overall set (108 data) } & sum \\
\hline category & 0 & 1 & \\
\hline 0 & $71(86.6 \%)$ & $11(13.4 \%)$ & $82(100 \%)$ \\
\hline 1 & $9(34.6 \%)$ & $17(65.4 \%)$ & $26(100 \%)$ \\
\hline \multicolumn{4}{|c|}{ correctness: $[(71+17) /(82+26)] \times 100 \%=81.48 \%$} \\
\hline
\end{tabular}

\section{2) Logistic regression analysis}

The regression function for debris flow potential analysis was further studied by Logistic Regression Analysis using the ten selected factors. The coefficients of function were obtained from logistic coefficient (B) in classification table of Logistic Regression Analysis (see Table IX). The regression equation was further examined by the Chi-square Test that was significantly ( $p$-value) smaller than 0.05 with acceptable goodness of fit in $95 \%$ of confidence interval. The regression function is listed as follows:

$Y=0.165 A_{s}+0.817 F-14.822 E-0.003 R_{f}-0.473 E_{d}+$ $14.150 F_{L}+0.490 \mathrm{G}-29.906 D_{A}+0.004 R_{W}+0.347 I_{W}-3.653$

Results of the Logistic Regression Analysis show that the correctness is $100 \%$ for non-debris flow sub-basins (category $\ulcorner 0\lrcorner$ ), $69.2 \%$ for debris flow sub-basins (category $\ulcorner 1\lrcorner$ ), with $92.6 \%$ of overall correctness.

TABLE IX: CLASSIFICATION COEFFICIENT TABLE BY LOGISTIC REGRESSION ANALYSIS

\begin{tabular}{|c|c|c|c|c|c|c|}
\hline Factor & $\mathrm{B}$ & S.E. & Wald & $\begin{array}{l}\text { degrees of } \\
\text { freedom }\end{array}$ & $\begin{array}{c}\text { p- } \\
\text { value }\end{array}$ & $\operatorname{Exp}(B)$ \\
\hline$A_{S}\left(\mathrm{~km}^{2}\right)$ & 0.165 & 0.084 & 3.827 & 1 & 0.050 & 1.179 \\
\hline$F$ & 0.817 & 0.595 & 1.881 & 1 & 0.170 & 2.263 \\
\hline$E$ & -14.822 & 12.049 & 1.513 & 1 & 0.219 & 0.000 \\
\hline$R_{f}(\mathrm{~m})$ & -0.003 & 0.002 & 2.064 & 1 & 0.151 & 0.997 \\
\hline$E_{d}$ & -0.473 & 0.574 & 0.681 & 1 & 0.409 & 0.623 \\
\hline$F_{L}$ & 14.150 & 20.144 & 0.493 & 1 & 0.482 & 1397007 \\
\hline$G$ & 0.490 & 0.392 & 1.565 & 1 & 0.211 & 1.632 \\
\hline$D_{A}$ & -29.906 & 22.055 & 1.839 & 1 & 0.175 & 0.000 \\
\hline$R_{w}(\mathrm{~mm})$ & 0.004 & 0.004 & 1.238 & 1 & 0.266 & 1.004 \\
\hline $\begin{array}{l}I_{w} \\
(\mathrm{~mm} / \mathrm{hr})\end{array}$ & 0.347 & 0.360 & 0.931 & 1 & 0.335 & 1.415 \\
\hline constant & -3.653 & 8.240 & 0.196 & 1 & 0.658 & 0.026 \\
\hline
\end{tabular}

3) Comparisons of the two analyzed methodologies

The correctness by Fisher's model is $69.23 \%$ for debris flow sub-basins and $95.12 \%$ for non-debris flow sub-basins, with an overall correctness of $81.48 \%$. The correctness is $69.23 \%$ for debris flow sub-basins and $100 \%$ for non-debris flow sub-basins, with an overall correctness of $92.6 \%$ by the Logistic Regression model. Fisher's model shows the same correctness for Logistic Regression model in category $\ulcorner 1\lrcorner$ (debris flow sub-basin); and lower than Logistic Regression model in category $\ulcorner 0\lrcorner$ (non-debris flow sub-basin). In general, the prediction model by Logistic Regression model has greater correctness than by Fisher's model. The study suggests using the regression function by Logistic Regression model for potential debris flow analysis and is expected to apply to other areas.

\section{CONCLUSION}

The study used Fisher's Discriminant Analysis and Logistic Regression Analysis for evaluation of debris flow potentials and its correctness by setting up a function of linear equation. The following list summarizes the results: 
1) There are 54 sub-basins, including 13 with and 41 without debris flow records, in the study area. Screening analysis for 19 topographic factors were analyzed using the Kolomogorov-Smironv test (K-S test), Mann-Whitney-Wilcoxon test (M-W-W test), Correlation Analysis, and Principal Component Analysis. Four main topographic factors, including effective watershed area, form factor, elongation ratio, and relief energy, were selected for the analysis.

2) Ten factors showed significant effects to the initiation of debris flow: Effective basin area, form factor, elongation ratio, relief energy, geologic index, fault length, landslide ratio, ratio of dip slope area, effective cumulative rainfall, and effective rainfall intensity.

3) The correctness for the debris flow sub-basins was $88.89 \%$ and $74.07 \%$ for the none-debris flow sub-basins. The overall correctness for the two sets was $81.48 \%$ using Fisher's Discriminant Analysis.

4) The correctness for the debris flow sub-basins was $69.23 \%$ and $100.0 \%$ for the none-debris flow sub-basins using Logistic Regression Analysis. The overall correctness for the two sets was $92.6 \%$ using Logistic Regression Analysis.

5) The study suggests using Logistic Regression Analysis for debris flow potential analysis in the study basin. The regression equation was set as: $\mathrm{Y}=0.165 \mathrm{~A}_{\mathrm{s}}+0.817 \mathrm{~F}$ $14.822 \mathrm{E}-0.003 \mathrm{R}_{\mathrm{f}}-0.473 \mathrm{E}_{\mathrm{d}}+14.150 \mathrm{~F}_{\mathrm{L}}+0.490 \mathrm{G}-$ $29.906 \mathrm{D}_{\mathrm{A}}+0.004 \mathrm{R}_{\mathrm{w}}+0.347 \mathrm{I}_{\mathrm{w}}-3.653$.

\section{REFERENCES}

[1] P. S. Lin, J. Y. Lin, J. C. Hung, and M. D. Yang, "Assessing debris-flow hazard in a watershed in Taiwan," Engineering Geology, vol. 66, pp. 295-313, 2002

[2] P. S. Lin, J. Y. Lin, S. Y. Lin, and J. Lai, "Hazard assessment of debris flows by statistical analysis and GIS in central Taiwan," International Journal of Applied Science and Engineering, vol. 4, no. 2, pp. 165-187, 2006.

[3] C. Y. Chen and F. C. Yu, "Morphometric analysis of debris flows and their source areas using GIS," Geomorphology, vol. 129, pp. 387-397, 2011.

[4] M. H. Lee, "A rainfall-based debris-flow warning analysis and its application," Ph.D. dissertation, Department of Hydraulics \& Ocean Engineering, National Cheng Kung University, Tainan, Taiwan R.O.C. 2006.

[5] W. H. Wu, "Debris flow potential analysis and outflow debris masses estimation," M.S. thesis, Department of Construction Engineering, Chaoyang University of Technology, Taichung, Taiwan R.O.C., 2006.

[6] C. Y. Chen, T. C. Chen, F. C. Yu, W. H. Yu, and C. C. Tseng, "Rainfall duration and debris-flow initiated studies for real-time monitoring," Environmental Geology, vol. 47, no. 5, pp. 715-724, 2005.
[7] C. C. Huang, "Gaussian-distribution-based hyetographs and their relationships with debris flow initiation," Journal of Hydrology, vol. 411, pp. 251-265, 2011.

[8] S. H. Cannon and S. D. Ellen, "Rainfall conditions for abundant debris avalanches, San Francisco Bay region," California Geology, vol. 38, no. 12 , pp. 267-272, 1985.

[9] G. Crosta and P. Frattini, "Rainfall thresholds for triggering soil slips and debris flow," in Proc. the 2nd Plinius International Conference on Mediterranean Storms, Siena, Italy, 2001, pp. 463-488.

[10] H. F. Kaiser, "The application of electronic computers to factor analysis," Educational and Pshchological Mesurement, vol. 20, pp. 141-151, 1960.

[11] S. E. Pratsinis, M. D. Zeldin, and E. C. Ellis, "Source resolution of the fine carbonaceous aerosol by principal component-stepwise regression analysis," Environ. Sci. Technol., vol. 22, pp. 212-216, 1988.

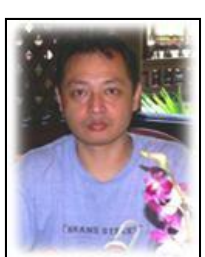

Chien-Yuan Chen was born on October 27, 1969, in Changhua City, Taiwan. He got his Ph.D. in civil \& environmental engineering, University of Southern California, Los Angeles, USA in 2001. M.Sc. in civil engineering, National Cheng Kung University, Taiwan in 1995.

He was an associate research fellow (2001-2006) at Slopeland Disaster Reduction Division, National Science and Technology Center for Disaster Reduction (NCDR), Sindian District, New Taipei City, Taiwan. He was an assistant professor (2006-2009) and associate professor (2009-2013) at the Department of Civil and Water Resources Engineering, National Chiayi University. $\mathrm{He}$ is currently as a professor (since 2013) at the Department of Civil and Water Resources Engineering, National Chiayi University, Chiayi City, Taiwan. His research is focused on the disaster prevention management and system, disaster prevention education, debris flow and landslide hazards prevention and mitigation, geotechincal engineering, GIS application and numerical modeling.

Prof. Chen is a member of Disaster Management Society of Taiwan.

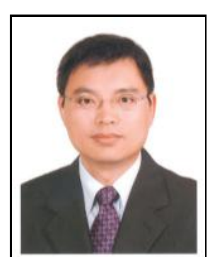

Ho-Wen Chen was born on February 4, 1970, in Changhua City, Taiwan. He got his Ph.D. in National Cheng Kung Univ, Taiwan in 2000. M.Sc. in environmental engineering, National Cheng Kung University, Taiwan, 1995. He was an assistant professor (2001-2006) and associate professor (2006-2010) at Department of Environmental Engineering and Management, Chaoyang University of Technology. He is currently as a professor (since 2010) at the Department of Environmental Science and Engineering, Tunghai University, Taichung City, Taiwan. His research is focused on sustainable system engineering, artificial intelligent and data mining, environmental informatics, water resources management, environmental forensics.

Zhao-Jun Chen was born on February 4, 1963, in Chiayi City, Taiwan. He received his M.Sc. in civil and water resources engineering, National Chiayi University. Taiwan, 2011. He is currently as an engineering in engineering consultant company. 